\title{
Unusual Structural Features of a Siloxane
}

\author{
WOLFGANG RIES*, THOMAS ALBRIGHT**, JEROME SILVESTRE, IVAN BERNAL ${ }^{\dagger}$ \\ Department of Chemistry, University of Houston, Houston, Tex. 77004, U.S.A.
}

WOLFGANG MALISCH and CHRISTIAN BURSCHKA ${ }^{\dagger}$

Institut für Chemie der Universität, Am Hubland, D-8700, Würzburg, F.R.G.

Received May 7, 1985

\begin{abstract}
Crystals of the R, S diastereoisomer of $\left[\mathrm{Cp}(\mathrm{CO})_{2}\right.$. $\left.\mathrm{FeSiCH}_{3} \mathrm{~F}\right]_{2} \mathrm{O}$ are monoclinic, space group $P 2_{1} / c$ (No. 14), with $a=846.0$ (3) [836.4(1)], $b=768.0$ (3) [757.1(1)], $\quad c=1548.5(4) \quad[1522.3(2)] \mathrm{pm}, \beta=$ $97.34(3)^{\circ}\left[97.47(3)^{\circ}\right]$ at $300 \mathrm{~K}[120 \mathrm{~K}]$ with $Z=$ 2. Even at $120 \mathrm{~K}$ the $\mathrm{Si}-\mathrm{O}-\mathrm{Si}$ fragment is found to be strictly linear due to crystallographically imposed symmetry. To explain the unusual electron distribution derived from the X-ray data collected, several types of possible disorders are discussed, none of which leads to a satisfying explanation. Retaining the $C_{i}$ symmetry (linear $\mathrm{Si}-\mathrm{O}-\mathrm{Si}$ fragment in the final model) the important bond lengths are $\mathrm{Fe}-\mathrm{Si} 226.7(1)$ [226.5(1)] pm, Si-F 160.9(2) [161.8(2)] pm, Si-O 160.3(1) [161.1(1)] pm, $\mathrm{Si}-\mathrm{C} 185.0(3)[185.6(3)] \mathrm{pm}$. The electronic features of this compound were probed via molecular orbital calculations of the extended Hückel type. It was found that the lone pairs on the siloxane oxygen were tipped away from cylindrical symmetry. The tipping was directed toward the fluorine substituents on the silicon atoms and away from the $\mathrm{CpFe}(\mathrm{CO})_{2}$ units. A pertubational approach was utilized to rationalize this effect.
\end{abstract}

\section{Introduction}

For reasons outlined in an earlier communication [1] we are interested in the chemical and structural properties of transition metal-substituted siloxanes. Here, we report the structure of the $\mathrm{R}, \mathrm{S}$ diastereoisomer of $\left[\mathrm{Cp}(\mathrm{CO})_{2} \mathrm{FeSiCH}_{3} \mathrm{~F}\right]_{2} \mathrm{O}$, featuring an extremely large bond angle at the bridging oxygen atom of $180^{\circ}$. The refinement of the structural parameters using X-ray data collected at room tem-

*NATO Research Fellow, University of Houston, Tex., $1981-1982$.

${ }^{* *}$ Camille and Henry Dreyfus Teacher-Scholar, 1980-1984; Alfred P. Sloan Research Fellow, 1982-1986.

tAuthors to whom correspondence should be addressed. perature revealed unusual values for the thermal parameters of some atoms. Therefore, we collected a data set at $120 \mathrm{~K}$ in an attempt to separate evident thermal effects from possible influences due to some type of disorder. In the present communication we will discuss the results of both refinements in detail, including the models developed to account for molecular disorder. In addition, we want to compare some structural and electron distribution features derived from our final model with the results of molecular orbital calculations at the extended Hückel level; computational details are given in the Experimental section. A general pattern will be presented which shows how very electropositive and electronegative substituents at the silicon atoms reorient the lone pairs at oxygen.

\section{Experimental}

Crystals of the R, S diastereoisomer of $\left[\mathrm{Cp}(\mathrm{CO})_{2}\right.$ $\left.\mathrm{FeSiCH}_{3} \mathrm{~F}\right]_{2} \mathrm{O}^{2}$ were obtained as the less soluble isomer by fractional crystallization from pentane. A crystal of $0.15 \times 0.25 \times 0.30 \mathrm{~mm}$ was mounted on a $\mathrm{X}-\mathrm{Y}-\mathrm{Z}$ translation head and onto a Syntex $P 2{ }_{1}$ diffractometer. The lattice constants listed in Table I are derived from least-squares fits of 17 carefully centered reflections in the range $25^{\circ}<$ $2 \theta<28^{\circ}$. A quadrant of the reflection sphere was measured using an $\omega$-scan technique. The reflections were corrected for absorption by means of a $\psi$-scan of 7 selected reflections.

For the low-temperature data set a crystal was ground to a sphere of approx. $0.30 \mathrm{~mm}$ in diameter and, after mounting and centering on the diffractometer, cooled to $120 \mathrm{~K}$. The temperature was monitored with a thermocouple permanently mounted inside the stream of cold $\mathrm{N}_{2}$. Thus, the temperature of the sample crystal was kept constant to within $\pm 3 \mathrm{~K}$ during the course of data collection.

Lorentz and polarization factors were applied in converting the intensities to structure factor amplitudes, $\left|F_{\mathbf{o}}\right|$. Table 1 gives a summary of crystallo- 
TABLE I. Summary of Data Collection and Processing Parameters

\begin{tabular}{|c|c|c|}
\hline & $300 \mathrm{~K}$ & $120 \mathrm{~K}$ \\
\hline Space group & \multicolumn{2}{|c|}{$P 2_{1} / c$} \\
\hline \multicolumn{3}{|l|}{ Cell constants } \\
\hline$a(\mathrm{pm})$ & $846.0(3)$ & $836.4(1)$ \\
\hline$b(\mathrm{pm})$ & $768.0(3)$ & $757.1(1)$ \\
\hline$c(\mathrm{pm})$ & $1548.5(4)$ & $1522.3(2)$ \\
\hline$\beta\left(^{\circ}\right)$ & $97.34(3)$ & $97.47(3)$ \\
\hline Cell volume, $V\left(\mathrm{~nm}^{3}\right)$ & 0.99785 & 0.95579 \\
\hline Molecular formula & \multirow{2}{*}{\multicolumn{2}{|c|}{$\begin{array}{l}\mathrm{C}_{16} \mathrm{H}_{16} \mathrm{~F}_{2} \mathrm{Fe}_{2} \mathrm{O}_{5} \mathrm{Si}_{2} \\
494.16\end{array}$}} \\
\hline Molecular weight & & \\
\hline Density, $\rho$ (calc.; $Z=2)\left(\mathrm{g} \mathrm{cm}^{-3}\right)$ & 1.644 & 1.717 \\
\hline Radiation & \multicolumn{2}{|c|}{$\operatorname{MoK} \alpha(\lambda=71.069 \mathrm{pm})$} \\
\hline Absorption coefficient, $\mu\left(\mathrm{cm}^{-1}\right)$ & 16.51 & 17.24 \\
\hline Data collection range & \multicolumn{2}{|c|}{$\begin{array}{l}5^{\circ} \leqslant 2 \theta \leqslant 50^{\circ} \\
1^{\circ}\end{array}$} \\
\hline Scan width, $\Delta \omega$ & & \\
\hline Total data collected & 2032 & 2032 \\
\hline Data with $I>3 \sigma(I)$ & 1536 & 1571 \\
\hline Total variables & 133 & 133 \\
\hline$R=\Sigma|| F_{\mathrm{o}}|-| F_{\mathrm{c}} \| / \Sigma\left|F_{\mathrm{o}}\right|$ & 0.0244 & 0.0294 \\
\hline$R_{w}=\left[\Sigma w^{2}\left(\left|F_{\mathrm{o}}-F_{\mathrm{c}}\right|\right)^{2} / \Sigma w^{2}\left|F_{\mathrm{o}}\right|^{2}\right]^{1 / 2}$ & 0.0246 & 0.0319 \\
\hline Weights, $w$ & & \\
\hline Goodness of fit & 0.62 & 0.91 \\
\hline Final difference density ${ }^{a}$ & $-0.18 \leqslant \rho \leqslant+0.39$ & $-0.43 \leqslant \rho \leqslant+0.86$ \\
\hline
\end{tabular}

aUnits $=\mathrm{e}^{3} \times 10^{-6} \mathrm{pm}^{-3}$.

graphically important parameters. The observed absences $(h 0 l, l=2 n+1 ; 0 k 0, k=2 n+1)$ indicated uniquely the space group $P 2_{1} / c$, requiring one-half molecule in the asymmetric unit. The structure was solved by interpretation of the three-dimensional Patterson function resulting in the positions for iron and silicon.

Successive difference Fourier maps yielded the coordinates of all non-hydrogen atoms. After several cycles of refinement and conversion to anisotropic thermal parameters all hydrogen atoms could be located from a difference Fourier map but were kept at idealized positions $\left(d_{\mathrm{CH}}=100 \mathrm{pm}, 108 \mathrm{pm}\right)$ and only their isotropic temperature factors were allowed to refine. Table I lists the final agreement factors with $R_{w}$ minimized during refinement.

The atomic scattering curves of Cromer and Mann [2] were used for the nonhydrogen atoms and for hydrogen the curve of Stewart et al. [3] was used. Corrections for the real and imaginary part of the anomalous dispersion for $\mathrm{Fe} \mathrm{[4]} \mathrm{were} \mathrm{also} \mathrm{applied.}$ All calculations were carried out using the Syntex XTL System on a Nova 1200 minicomputer [5] and the SHELX76 system [6] of programs on a Honeywell mainframe. The stereo plots were obtained by using Johnson's ORTEP II [7]. Tables II and III list the final positional and thermal parameters for $300 \mathrm{~K}$ and $120 \mathrm{~K}$, respectively, and Table IV, $\mathrm{V}$ and VI present intramolecular bond lengths, bond angles and torsional angles, respectively, for both refinements. Least-squares planes are given in Table VI.B.

All bond lengths and angles for $\left[\mathrm{CpFe}(\mathrm{CO})_{2} \mathrm{Si}\right.$ $\mathrm{HF}]_{2} \mathrm{O}$ were taken from the experimental structure. The parameters for the extended Hückel calculations [8] were taken from previous work [9] and are listed in Table VII. A modified Wolfsberg-Helmholtz method [10] was utilized. A Si-H distance of $1.49 \AA$ with an $\mathrm{H}-\mathrm{Si}-\mathrm{O}$ angle of $106.8^{\circ}$ was employed throughout. In the model compounds $\left(\mathrm{H}_{2} \mathrm{XSi}\right)_{2} \mathrm{O}$ and $\left(\mathrm{H}_{2} \mathrm{ASi}\right)_{2} \mathrm{O} X$ and $\mathrm{A}$ are taken to be electronegative and electropositive substituents, respectively. The $\mathrm{H}_{\mathrm{ii}}$ for $\mathrm{X}$ was $-22.0 \mathrm{eV}$ and $\mathrm{A}$ was $-7.0 \mathrm{eV}$; in both cases the orbital exponent for $\mathrm{H}$ (see Table VII) was used along with the same bond length and angles.

\section{Results and Discussion}

Before discussing the most important feature of this structure, the extremely large intramolecular bond angle at the bridging oxygen atom, we present the conventional details to illustrate that, in general, there is nothing peculiar about this case, i.e., our results are derived from a level of structural refine. ment which is usually considered to be sufficient.

For the comparison of the room-temperature and the low-temperature data set, it has to be noted that the former was collected using a suitable crystal in 
TABLE II. Atomic Coordinates and Thermal Parameters $(\times 1000 ; \mathrm{Fe}, \mathrm{Si} \times 10000)$ for $300 \mathrm{~K}$

\begin{tabular}{|c|c|c|c|c|c|c|c|c|c|}
\hline Atom & $x / a$ & $y / b$ & $z / c$ & $U_{11}$ & $U_{22}$ & $U_{33}$ & $U_{12}$ & $U_{13}$ & $U_{23}$ \\
\hline $\mathrm{Fe}$ & $0.23499(4)$ & $0.20123(5)$ & $0.36400(2)$ & $365(2)$ & $416(2)$ & $392(2)$ & $-17(2)$ & $-2(1)$ & $14(2)$ \\
\hline $\mathrm{Si}$ & $0.46614(9)$ & $0.05337(11)$ & $0.39923(5)$ & $434(4)$ & $546(5)$ & $531(4)$ & $80(4)$ & $39(3)$ & $87(4)$ \\
\hline$F$ & $0.4595(3)$ & $-0.1304(3)$ & $0.3489(2)$ & $97(2)$ & $62(1)$ & $145(2)$ & $25(1)$ & $6(1)$ & $-25(1)$ \\
\hline $\mathrm{O} 1$ & $0.2714(3)$ & $0.1156(4)$ & $0.1856(1)$ & $104(2)$ & $118(2)$ & $42(1)$ & $-19(2)$ & $33(2)$ & $-15(1)$ \\
\hline $\mathrm{O} 2$ & $0.0744(3)$ & $-0.1193(3)$ & $0.3967(2)$ & $97(2)$ & $68(2)$ & $138(2)$ & $-36(2)$ & $33(2)$ & $5(2)$ \\
\hline O3 & $0.5000(0)$ & $0.0000(0)$ & $0.5000(0)$ & $72(2)$ & $134(3)$ & $74(2)$ & $30(2)$ & $2(2)$ & $53(2)$ \\
\hline $\mathrm{Cl}$ & $0.2572(3)$ & $0.1504(4)$ & $0.2564(2)$ & $55(2)$ & $63(2)$ & $49(2)$ & $-9(1)$ & $7(1)$ & $2(1)$ \\
\hline $\mathrm{C} 2$ & $0.1389(3)$ & $0.0073(4)$ & $0.3833(2)$ & $52(2)$ & $57(2)$ & $67(2)$ & $-7(1)$ & $9(1)$ & $-4(2)$ \\
\hline $\mathrm{C} 3$ & $0.6488(4)$ & $0.1598(6)$ & $0.3708(3)$ & $45(2)$ & $109(3)$ & $95(3)$ & $8(2)$ & $18(2)$ & $25(2)$ \\
\hline $\mathrm{C} 11$ & $0.1598(4)$ & $0.4606(4)$ & $0.3396(2)$ & $83(2)$ & $51(2)$ & $84(2)$ & $14(2)$ & $-7(2)$ & $9(2)$ \\
\hline $\mathrm{C} 12$ & $0.3205(4)$ & $0.4557(4)$ & $0.3780(2)$ & $62(2)$ & $46(2)$ & $85(2)$ & $-10(2)$ & $12(2)$ & $0(2)$ \\
\hline $\mathrm{C} 13$ & $0.3239(4)$ & $0.3785(4)$ & $0.4599(2)$ & $80(2)$ & $50(2)$ & $63(2)$ & $-6(2)$ & $-10(2)$ & $-11(2)$ \\
\hline C14 & $0.1705(5)$ & $0.3324(5)$ & $0.4713(2)$ & $104(3)$ & $60(2)$ & $72(2)$ & $-8(2)$ & $38(2)$ & $-16(2)$ \\
\hline $\mathrm{C} 15$ & $0.0687(4)$ & $0.3845(5)$ & $0.3974(3)$ & $52(2)$ & $68(2)$ & $127(3)$ & $10(2)$ & $17(2)$ & $-19(2)$ \\
\hline H3A & $0.6738(4)$ & $0.2725(6)$ & $0.4120(3)$ & $116(8)$ & & & & & \\
\hline H3B & $0.6344(4)$ & $0.1997(6)$ & $0.3034(3)$ & $116(8)$ & & & & & \\
\hline $\mathrm{H} 3 \mathrm{C}$ & $0.7465(4)$ & $0.0688(6)$ & $0.3824(3)$ & $116(8)$ & & & & & \\
\hline H11 & $0.1195(4)$ & $0.5090(4)$ & $0.2809(2)$ & $97(12)$ & & & & & \\
\hline $\mathrm{H} 12$ & $0.4147(4)$ & $0.5002(4)$ & $0.3518(2)$ & $87(11)$ & & & & & \\
\hline H13 & $0.4212(4)$ & $0.3591(4)$ & $0.5027(2)$ & $95(12)$ & & & & & \\
\hline H14 & $0.1369(5)$ & $0.2730(5)$ & $0.5235(2)$ & $103(13)$ & & & & & \\
\hline H15 & $-0.0497(4)$ & $0.3697(5)$ & $0.3880(3)$ & $137(16)$ & & & & & \\
\hline
\end{tabular}

TABLE III. Atomic Coordinates and Thermal Parameters $(\times 1000 ; \mathrm{Fe}, \mathrm{Si} \times 10000)$ for $120 \mathrm{~K}$

\begin{tabular}{|c|c|c|c|c|c|c|c|c|c|}
\hline Atom & $x / a$ & $y / b$ & $z / c$ & $U_{11}$ & $U_{22}$ & $U_{33}$ & $U_{12}$ & $U_{13}$ & $U_{23}$ \\
\hline $\mathrm{Fe}$ & $0.23409(5)$ & $0.20754(6)$ & $0.36065(3)$ & $208(2)$ & $276(2)$ & $258(2)$ & $1(2)$ & $34(2)$ & $1(2)$ \\
\hline $\mathrm{Si}$ & $0.46772(10)$ & $0.05800(12)$ & $0.39737(6)$ & $238(4)$ & $338(5)$ & $368(5)$ & $32(4)$ & $54(3)$ & $54(4)$ \\
\hline$F$ & $0.4620(3)$ & $-0.1270(3)$ & $0.3439(2)$ & $43(1)$ & $36(1)$ & $97(2)$ & $9(1)$ & $6(1)$ & $-16(1)$ \\
\hline $\mathrm{O} 1$ & $0.2759(3)$ & $0.1207(3)$ & $0.1796(2)$ & $44(1)$ & $58(2)$ & $29(1)$ & $-11(1)$ & $8(1)$ & $-9(1)$ \\
\hline $\mathrm{O} 2$ & $0.0723(3)$ & $-0.1194(3)$ & $0.3937(2)$ & $44(1)$ & $36(1)$ & $68(2)$ & $-12(1)$ & $18(1)$ & 1(1) \\
\hline $\mathrm{O} 3$ & $0.5000(0)$ & $0.0000(0)$ & $0.5000(0)$ & $39(2)$ & $86(3)$ & $50(2)$ & $19(2)$ & $8(2)$ & $39(2)$ \\
\hline $\mathrm{C} 1$ & $0.2593(4)$ & $0.1559(4)$ & $0.2511(2)$ & $25(2)$ & $33(2)$ & $37(2)$ & $-2(1)$ & $3(1)$ & $2(1)$ \\
\hline $\mathrm{C} 2$ & $0.1364(4)$ & $0.0099(4)$ & $0.3802(2)$ & $25(2)$ & $36(2)$ & $39(2)$ & $2(1)$ & $9(1)$ & $-3(1)$ \\
\hline $\mathrm{C} 3$ & $0.6541(4)$ & $0.1684(5)$ & $0.3715(3)$ & $23(2)$ & $53(2)$ & $51(2)$ & $4(1)$ & $9(1)$ & $7(2)$ \\
\hline $\mathrm{C} 11$ & $0.1613(4)$ & $0.4720(4)$ & $0.3346(2)$ & $38(2)$ & $29(2)$ & $43(2)$ & $5(1)$ & $1(1)$ & $5(1)$ \\
\hline $\mathrm{C} 12$ & $0.3242(4)$ & $0.4647(4)$ & $0.3768(2)$ & $30(2)$ & $31(2)$ & $39(2)$ & $-6(1)$ & $7(1)$ & $-1(1)$ \\
\hline $\mathrm{C} 13$ & $0.3224(4)$ & $0.3842(4)$ & $0.4607(2)$ & $35(2)$ & $34(2)$ & $33(2)$ & $-4(1)$ & $1(1)$ & $-5(1)$ \\
\hline $\mathrm{C} 14$ & $0.1624(4)$ & $0.3394(5)$ & $0.4688(2)$ & $43(2)$ & $34(2)$ & $37(2)$ & $-3(1)$ & $17(1)$ & $-6(1)$ \\
\hline $\mathrm{C} 15$ & $0.0637(4)$ & $0.3941(4)$ & $0.3914(2)$ & $26(2)$ & $33(2)$ & $61(2)$ & $3(1)$ & $9(2)$ & $-7(2)$ \\
\hline $\mathrm{H} 3 \mathrm{~A}$ & $0.6788(4)$ & $0.2805(5)$ & $0.4150(3)$ & $55(6)$ & & & & & \\
\hline $\mathrm{H} 3 \mathrm{~B}$ & $0.6435(4)$ & $0.2121(5)$ & $0.3034(3)$ & $55(6)$ & & & & & \\
\hline $\mathrm{H} 3 \mathrm{C}$ & $0.7514(4)$ & $0.0742(5)$ & $0.3837(3)$ & $55(6)$ & & & & & \\
\hline H11 & $0.1238(4)$ & $0.5231(4)$ & $0.2749(2)$ & $44(10)$ & & & & & \\
\hline $\mathrm{H} 12$ & $0.4216(4)$ & $0.5086(4)$ & $0.3518(2)$ & $52(11)$ & & & & & \\
\hline $\mathrm{H} 13$ & $0.4181(4)$ & $0.3630(4)$ & $0.5060(2)$ & $41(10)$ & & & & & \\
\hline $\mathrm{H} 14$ & $0.1243(4)$ & $0.2794(5)$ & $0.5208(2)$ & $39(9)$ & & & & & \\
\hline $\mathrm{H} 15$ & $0.0560(4)$ & $0.3792(4)$ & $0.3794(2)$ & $60(12)$ & & & & & \\
\hline
\end{tabular}

its original shape, whereas for the latter a different crystal was ground to a sphere to avoid any systematic error caused by absorption. Therefore, the slightly higher agreement factor at low temperature should be mainly due to the imperfect molec- ular model and not to the conditions of data collection.

Crystals of $\left[\mathrm{Cp}(\mathrm{CO})_{2} \mathrm{FeSiCH}_{3} \mathrm{~F}\right]_{2} \mathrm{O}$ contain molecules with crystallographically imposed $C_{i}$ symmetry. The geometrical details of the $\mathrm{Cp}(\mathrm{CO})_{2} \mathrm{Fe}$ moiety 
TABLE IV. Intramolecular Bond Distances $(\mathrm{pm})^{\mathrm{a}}$

\begin{tabular}{lll}
\hline & $300 \mathrm{~K}$ & $120 \mathrm{~K}$ \\
\hline $\mathrm{Fe}-\mathrm{C} 1$ & $174.4(3)$ & $175.2(3)$ \\
$\mathrm{Fe}-\mathrm{C} 2$ & $174.1(3)$ & $174.9(3)$ \\
$\mathrm{Fe}-\mathrm{C} 11$ & $211.0(3)$ & $211.5(3)$ \\
$\mathrm{Fe}-\mathrm{C} 12$ & $208.6(3)$ & $209.1(3)$ \\
$\mathrm{Fe}-\mathrm{C} 13$ & $208.3(3)$ & $208.8(3)$ \\
$\mathrm{Fe}-\mathrm{C} 14$ & $207.5(3)$ & $208.0(3)$ \\
$\mathrm{Fe}-\mathrm{C} 15$ & $210.1(3)$ & $210.2(3)$ \\
$\mathrm{C} 1-\mathrm{O} 1$ & $115.0(3)$ & $114.7(4)$ \\
$\mathrm{C} 2-\mathrm{O} 2$ & $114.6(3)$ & $114.8(4)$ \\
$\mathrm{Fe}-\mathrm{Ce}$ & $172.2(1)$ & $171.7(1)$ \\
$\mathrm{Fe}-\mathrm{Si}$ & $226.7(1)$ & $226.5(1)$ \\
$\mathrm{Si}-\mathrm{C} 3$ & $185.0(3)$ & $185.6(3)$ \\
$\mathrm{Si}-\mathrm{F}$ & $160.9(2)$ & $161.8(2)$ \\
$\mathrm{Si}-\mathrm{O} 3$ & $160.3(1)$ & $161.1(1)$ \\
$\mathrm{C} 11-\mathrm{C} 12$ & $141.3(4)$ & $143.0(4)$ \\
$\mathrm{C} 12-\mathrm{C} 13$ & $139.7(4)$ & $141.6(4)$ \\
$\mathrm{C} 13-\mathrm{C} 14$ & $137.8(4)$ & $140.1(4)$ \\
$\mathrm{C} 14-\mathrm{C} 15$ & $140.0(5)$ & $141.0(5)$ \\
$\mathrm{C} 15-\mathrm{C} 11$ & $138.3(5)$ & $139.6(5)$ \\
$\mathrm{C}-\mathrm{C}$ av & $139.4(6)$ & $141.1(6)$ \\
\hline
\end{tabular}

${ }^{a} \mathrm{Ce}$ refers to the geometrical center of the cyclopentadienyl ring.

TABLE V. Intramolecular Bond Angles $\left({ }^{\circ}\right)^{a}$

\begin{tabular}{lrr}
\hline & $300 \mathrm{~K}$ & \multicolumn{1}{c}{$120 \mathrm{~K}$} \\
\hline $\mathrm{Si}-\mathrm{Fe}-\mathrm{Cl}$ & $85.6(1)$ & $85.2(1)$ \\
$\mathrm{Si}-\mathrm{Fe}-\mathrm{C} 2$ & $86.4(1)$ & $86.4(1)$ \\
$\mathrm{Si}-\mathrm{Fe}-\mathrm{Ce}$ & $120.3(1)$ & $120.3(1)$ \\
$\mathrm{C} 1-\mathrm{Fe}-\mathrm{C} 2$ & $94.7(1)$ & $95.0(1)$ \\
$\mathrm{C} 1-\mathrm{Fe}-\mathrm{Ce}$ & $128.6(1)$ & $128.7(1)$ \\
$\mathrm{C} 2-\mathrm{Fe}-\mathrm{Ce}$ & $127.6(1)$ & $127.5(1)$ \\
$\mathrm{C} 15-\mathrm{C} 11-\mathrm{C} 12$ & $107.5(3)$ & $107.7(3)$ \\
$\mathrm{C} 11-\mathrm{C} 12-\mathrm{C} 13$ & $107.5(3)$ & $107.5(3)$ \\
$\mathrm{C} 12-\mathrm{C} 13-\mathrm{C} 14$ & $108.4(3)$ & $107.9(3)$ \\
$\mathrm{C} 13-\mathrm{C} 14-\mathrm{C} 15$ & $108.2(3)$ & $108.5(3)$ \\
$\mathrm{C} 14-\mathrm{C} 15-\mathrm{C} 11$ & $108.4(3)$ & $108.4(3)$ \\
$\mathrm{Fe}-\mathrm{Si}-\mathrm{F}$ & $110.3(1)$ & $109.9(1)$ \\
$\mathrm{Fe}-\mathrm{Si}-\mathrm{C} 3$ & $116.3(1)$ & $116.4(1)$ \\
$\mathrm{Fe}-\mathrm{Si}-\mathrm{O} 3$ & $113.8(1)$ & $114.0(1)$ \\
$\mathrm{F}-\mathrm{Si}-\mathrm{C} 3$ & $104.5(2)$ & $104.7(1)$ \\
$\mathrm{F}-\mathrm{Si}-\mathrm{O} 3$ & $103.8(1)$ & $104.0(1)$ \\
$\mathrm{C} 3-\mathrm{Si}-\mathrm{O} 3$ & $107.1(1)$ & $106.8(1)$ \\
$\mathrm{Fe}-\mathrm{C} 1-\mathrm{O} 1$ & $179.5(3)$ & $179.5(3)$ \\
$\mathrm{Fe}-\mathrm{C} 2-\mathrm{O} 2$ & $179.2(3)$ & $179.4(3)$ \\
$\mathrm{Si}-\mathrm{O} 3-\mathrm{Si}$ & $180.0(0)$ & $180.0(0)$ \\
\hline
\end{tabular}

${ }^{a} \mathrm{Ce}$ refers to the geometrical center of the cyclopentadienyl ring. $\mathrm{Si}^{\prime}$ refers to the symmetry equivalent position $(1-x$, $\bar{y}, 1-z)$.

are in excellent agreement with those reported for $\left[\mathrm{Cp}(\mathrm{CO})_{2} \mathrm{Fe}\right]_{n} \mathrm{Si}_{3} \mathrm{Cl}_{6-\mathrm{n}} \mathrm{C}_{3} \mathrm{H}_{6}(\mathrm{n}=1,2)[11]$, not only in bond lengths, but also concerning the angles around iron $\left(\mathrm{Si}-\mathrm{Fe}-\mathrm{C}=85.9^{\circ} ; \mathrm{Cl}-\mathrm{Fe}-\mathrm{C} 2=94.8\right.$
TABLE VI. Selected Torsion Angles ${ }^{a}$ (a) and Least-Squares Planes and Deviations Therefrom in pm, Plane Defined by $\mathrm{C} 11, \mathrm{C} 12, \ldots \mathrm{C} 15$ (b)

\begin{tabular}{lrr}
\hline & $300 \mathrm{~K}$ & \multicolumn{1}{c}{$120 \mathrm{~K}$} \\
\hline (a) & & \\
$\mathrm{C} 1-\mathrm{Fe}-\mathrm{Si}-\mathrm{F}$ & -47.6 & -46.5 \\
$\mathrm{C} 2-\mathrm{Fe}-\mathrm{Si}-\mathrm{F}$ & 47.4 & 48.8 \\
$\mathrm{C} 2-\mathrm{Fe}-\mathrm{Si}-\mathrm{O} 3$ & -68.7 & -67.5 \\
$\mathrm{Ce}-\mathrm{Fe}-\mathrm{Si}-\mathrm{O} 3$ & 63.4 & 64.5 \\
$\mathrm{C} 1-\mathrm{Fe}-\mathrm{Si}-\mathrm{C} 3$ & 71.1 & 72.2 \\
$\mathrm{Ce}-\mathrm{Fe}-\mathrm{Si}-\mathrm{C} 3$ & -61.7 & -60.5 \\
$\mathrm{C} 13-\mathrm{Ce}-\mathrm{Fe}-\mathrm{Si}$ & -12.2 & -13.8 \\
$\mathrm{C} 11-\mathrm{Ce}-\mathrm{Fe}-\mathrm{Cl}$ & 22.2 & 21.0 \\
$\mathrm{C} 15-\mathrm{Ce}-\mathrm{Fe}-\mathrm{C} 2$ & -45.0 & -46.9 \\
(b) & & \\
$\mathrm{C} 11$ & & $-0.5(3)^{\mathrm{c}}$ \\
$\mathrm{C} 12$ & $-0.4(3)^{\mathrm{b}}$ & $0.6(3)^{\mathrm{c}}$ \\
$\mathrm{C} 13$ & $0.7(3)^{\mathrm{b}}$ & $-0.7(3)^{\mathrm{c}}$ \\
$\mathrm{C} 14$ & $-0.8(3)^{\mathrm{b}}$ & $0.4(3)^{\mathrm{c}}$ \\
$\mathrm{C} 15$ & $0.8(4)^{\mathrm{b}}$ & $0.0(3)^{\mathrm{c}}$ \\
$\mathrm{Fe}$ & $-0.3(4)^{\mathrm{b}}$ & $171.7(1)^{\mathrm{c}}$ \\
\hline
\end{tabular}

${ }^{\mathrm{a}} \mathrm{Ce}$ refers to the geometric center of the cyclopentadienyl ring. $\quad b_{0} .1729 x-0.8936 y-0.4143 z+5.200=0$.

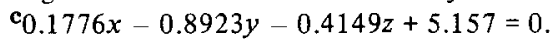

TABLE VII. Parameters for the Extended Hückel Calculations

\begin{tabular}{|c|c|c|c|c|c|c|}
\hline \multicolumn{2}{|c|}{ Orbital } & \multirow{2}{*}{$\frac{\mathrm{H}_{\mathrm{ii}}(\mathrm{eV})}{-9.17}$} & \multirow{2}{*}{$\frac{\xi_{1}}{1.90}$} & \multirow[t]{2}{*}{$\xi_{2}$} & \multirow[t]{2}{*}{$C_{1}^{a}$} & \multirow[t]{2}{*}{$C_{2}^{a}$} \\
\hline & e $4 \mathrm{~s}$ & & & & & \\
\hline & $4 p$ & -5.37 & 1.90 & & & \\
\hline & $3 \mathrm{~d}$ & -12.70 & 5.35 & 1.80 & 0.5366 & 0.6678 \\
\hline \multirow{2}{*}{$\mathrm{Si}$} & i $3 \mathrm{~s}$ & -17.30 & 1.383 & & & \\
\hline & $3 p$ & -9.20 & 1.383 & & & \\
\hline \multirow{2}{*}{ C } & $2 \mathrm{~s}$ & -21.40 & 1.625 & & & \\
\hline & $2 \mathrm{p}$ & -11.40 & 1.625 & & & \\
\hline \multirow[t]{2}{*}{0} & $2 s$ & -32.30 & 2.275 & & & \\
\hline & $2 \mathrm{p}$ & -14.80 & 2.275 & & & \\
\hline \multirow{2}{*}{$\mathrm{F}$} & $2 \mathrm{~s}$ & -40.00 & 2.425 & & & \\
\hline & $2 \mathrm{p}$ & -18.10 & 2.425 & & & \\
\hline $\mathrm{H}$ & $1 \mathrm{~s}$ & -13.60 & 1.30 & & & \\
\hline
\end{tabular}

${ }^{\mathrm{a}}$ Contraction coefficients used in the double-zeta expansion.

vs. $87.6^{\circ}, 94.2^{\circ}$ in the cyclosilanes). None of the corresponding bond lengths show deviations larger than $3 \sigma$ from those reported for the monometallated species. The increase in average $\mathrm{C}-\mathrm{C}$ distance for the cyclopentadienyl ring system in the low-temperature refinement is, though barely, greater than $1 \sigma$ and consistent with the expectations that reducing the 
rotational motion would allow for a better representation of the cyclopentadienyl ring.

The $\mathrm{Si}-\mathrm{F}$ and $\mathrm{Si}-\mathrm{C}$ distances are well within the range observed for other accurate fluorosilane structures (Si-F: 155.4 pm-160.6 pm [12]; Si-C: $182.8 \mathrm{pm}-187.4 \mathrm{pm}[12,13]$, and compare favorably to those observed for the metallated silicon compound $\mathrm{Cp}(\mathrm{CO})(\mathrm{H}) \mathrm{Fe}\left(\mathrm{SiF}_{2} \mathrm{CH}_{3}\right)_{2} \quad(\mathrm{Si}-\mathrm{F}: 159.6$ $\mathrm{pm} ; \mathrm{Si}-\mathrm{C}: 183.6 \mathrm{pm} \mathrm{[14])}$ and the monometallated cyclosilane $\left(\mathrm{Si}-\mathrm{C}_{\mathrm{av}}: 186.1 \mathrm{pm}\right)$. The deviations from ideal tetrahedral geometry around the silicon atom, as observed earlier, show increased bond angles between stronger $\sigma$-donor substituents and vice versa.

The following discussion of the $\mathrm{Si}-\mathrm{O}-\mathrm{Si}$ fragment is due to the lasting dispute in the literature of whether bonding angles close to $180^{\circ}$ are misrepresentations [15] or highly probable [16], since the $\mathrm{Si}-\mathrm{O}$ bond length was shown to have variances bigger than necessary to adapt to angle changes from a stressed linear three-atom arrangement to a valence angle of approx. $150^{\circ}$, even in such a closely limited class as silicates [17]. The only known case of a neutral molecular compound for which an $\mathrm{Si}-\mathrm{O}-\mathrm{Si}$ angle of $180^{\circ}$ had been determined earlier, $\left[\left(\mathrm{C}_{6} \mathrm{H}_{5}\right)_{3} \mathrm{Si}\right]_{2} \mathrm{O}$ [18], also has $C_{i}$ symmetry (demanding linearity), but there are cases such as $\left[(\mathrm{CpVI})_{2}\{\mathrm{CpV}(\mathrm{NO})\}_{2}\right.$ $(\mu-O)_{4}$ ] [19] with an extremely large $\mathrm{M}-\mathrm{O}-\mathrm{M}$ angle and 0 in general position. This supports the plausibility of having a large bond angle at oxygen and, from theoretical considerations [20], an extremely low potential for bending at this atom.

*Wells [21] points out that systems such as $\mathrm{M}^{\mathrm{iv}} \mathrm{P}_{2} \mathrm{O}_{7}$ $\mathrm{M}^{\mathrm{ii}} \mathrm{P}_{2} \mathrm{O}_{7}$ and $\mathrm{M}^{\mathrm{i}} \mathrm{P}_{2} \mathrm{O}_{7}$ (for example $\mathrm{Z}_{4} \mathrm{P}_{2} \mathrm{O}_{7}$ ) were thought to contain linear $\mathrm{O}_{3} \mathrm{P}-\mathrm{O}-\mathrm{PO}_{3}$ ions. $\mathrm{A}$ more careful analysis of these structures revealed that this was an error introduced by overlooking the true lattice symmetry - a supperlattice 27 times larger than that used in the earlier work.
The $\mathrm{Si}-\mathrm{O}-\mathrm{Si}$ bond system must be strictly linear in our compound because of the molecular symmetry, $C_{i}$. But, this is true only if the correct space group is indeed $P 2_{1} / c$ as deduced in the Experimental section. A careful check of the rotational photographs and measurements with the counting chain of the diffractometer revealed no significant reflected $\mathrm{X}$-ray intensity between lattice rows of the proposed lattice (Table I), thus eliminating any doubling of axial lengths which might have been caused by a superstructure*. Therefore, the space group is uniquely identified by the observed absences as $P 2_{1} / c$.

The thermal parameters (listed in Table II; stored) illustrated in Fig. 1 show no peculiarities for $\mathrm{Fe}, \mathrm{Si}$, $\mathrm{C}$ and the carbonyl oxygen atoms. In contrast to this, 03 and $\mathrm{F}$ show unusually high values for $U_{22}, U_{12}$, $U_{23}(\mathrm{O} 3)$ and $U_{33}, U_{12}, U_{23}(\mathrm{~F})$, respectively, leading to considerably elongated thermal ellipsoids with their main axis not perpendicular to the $\mathrm{Si}-\mathrm{O} 3$ and $\mathrm{Si}-\mathrm{F}$ bond. This initiated the collection of a data set at $120 \mathrm{~K}$, using a spherical sample, since this observation could be an indicator of static or dynamic disorder** not resolved in the room-temperature refinement. Cooling of the sample did not result in a change of space group, a process well known in the literature [23] which could reveal the freezing of dynamic disorder with different occupancies for the interchanging sites. The low-temperature refinement shows even a higher deviation for $\mathrm{O} 3$ and $\mathrm{F}$ from spherical shape for the thermal ellipsoids. This could indicate that $\mathrm{O} 3$ is disordered statistically over two positions or has a low barrier dynamic interchange. A refinement with $\mathrm{O3}$, not restricted to the special position, leads to a position M2 ( $x=0.4921, y=$ $-0.0252, z=0.4896)$, which is unreasonable due

**Calvo [22] points out that the structures of divalent pyrophosphates show either a bent $\mathrm{O}_{3} \mathrm{P}-\mathrm{O}-\mathrm{PO}_{3}$ groups or considerable disorder of the central atom of the anion.
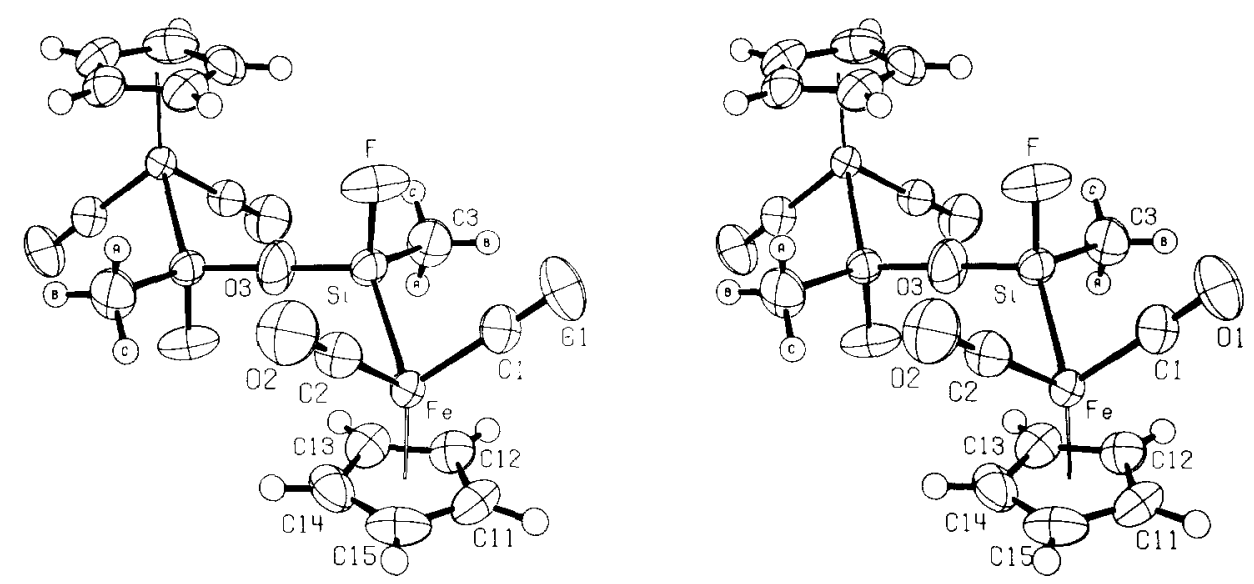

Fig. 1. A stereoview of the molecule showing the labelling system used in the crystallographic study. The ellipsoids displayed are $50 \%$ equiprobability envelopes. The coordinates used in drawing the molecule are those derived from the low-temperature study $(120 \mathrm{~K})$. 

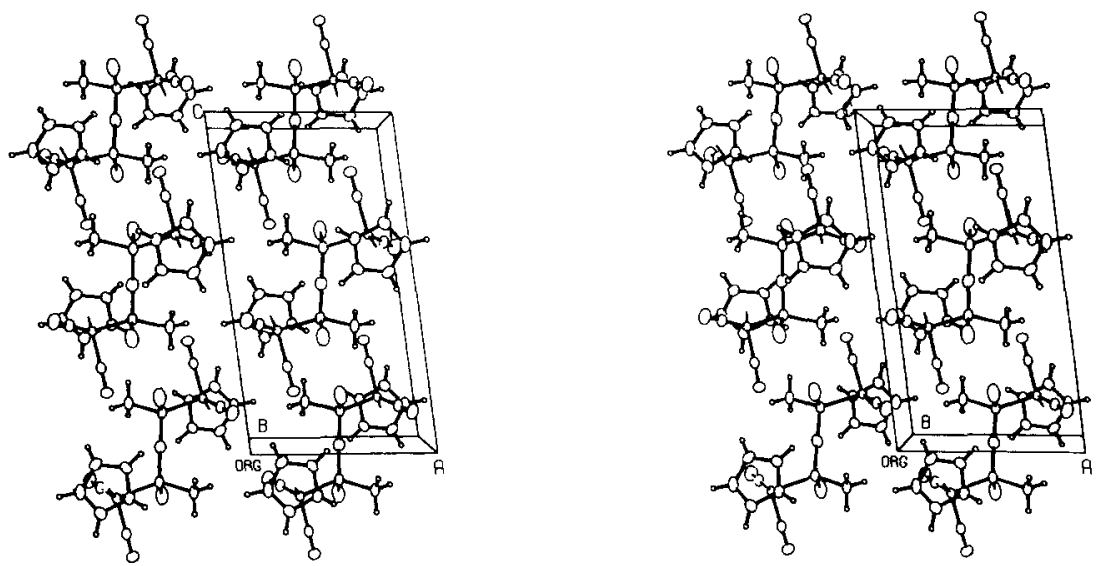

Fig. 2. Packing of the molecules in the unit cell.

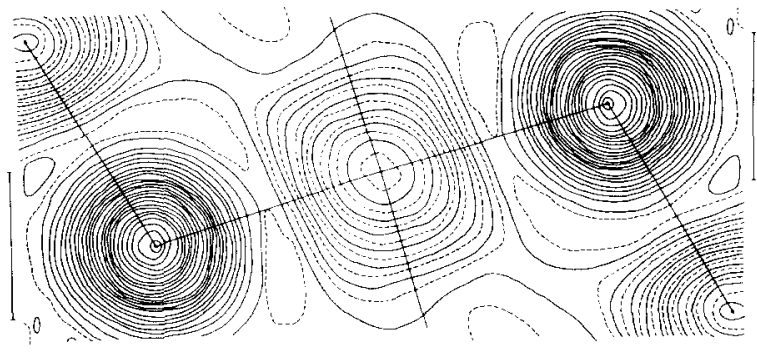

Fig. 3. An electron density map showing the section passing through the $\mathrm{Si}, \mathrm{F}$ and $\mathrm{O} 3$ atoms. Note that this section is very close to the main axis of vibration of the $\mathrm{Si}-\mathrm{O}$ moiety. The contours (-) are ca. $3 \times 10^{-6} \mathrm{e} \mathrm{pm}^{-3}$. (See text for further details.)

to the differences in values for the chemically equivalent $\mathrm{Si}-\mathrm{O}$ bond lengths (153 pm vs. $173 \mathrm{pm}$ ). This corresponds to a shift for the oxygen atoms, away from the inversion center, along a vector indicated by the main axis of vibration in the ordered model. To find the reason for this unusual behavior, we calculated the electron density in a plane containing $\mathrm{Si}, \mathrm{F}$ and $\mathrm{O} 3$, which is very close to the plane defined by the main axis of vibration for $\mathrm{O} 3$ and the $\mathrm{Si}-\mathrm{O}$ vector, as evident from Figs. 1 and 2. Figure 3 depicts the electron density in this plane in contours of electron density of approx. $3 \times 10^{-6} \mathrm{e} \mathrm{pm}^{-3}$ and demonstrates that the net charge in the quadrant oriented towards the F substituent is definitely higher than in the quadrant oriented towards the methyl and iron substituents, which, of course, are of $f$ the plane. The refinement and calculation of a difference Fourier map with isotropic thermal parameters for O3 showed the highest difference density $\left(1.6 \times 10^{-6}\right.$ e $\left.\mathrm{pm}^{-3}\right)$ at a position Ml $(x=0.483, y=-0.065$, $z=0.478$ ) having a displacement vector from the inversion center almost collinear to the disordered model, but about twice as long. This indicates that the disordered model in fact compensates for the deviations from twofold symmetry in electron density around the $\mathrm{Si}-\mathrm{O} 3$ bond.

The model with anisotropic temperature factors for oxygen at the inversion center shows a small electron surplus at its center $\left(-0.08 \times 10^{-6} \mathrm{e} \mathrm{pm}^{-3}\right)$ and a slightly higher deficit $\left(0.25 \times 10^{-6} \mathrm{e} \mathrm{pm}^{-3}\right)$ at a position M3 $(x=0.495, y=-0.025, z=0.465)$ closer to silicon than the other two calculations. The question arises: what trend is observable for these parameters if compared to those derived under equivalent conditions from the room-temperature data set?

The calculation of the difference Fourier maps using an isotropic temperature factor for $\mathrm{O} 3$ exhibits the highest peak at essentially the same position as for the low-temperature data, but with slightly less height $\left(1.2 \times 10^{-6} \mathrm{e} \mathrm{pm}^{-3}\right)$. The coordinates for $\mathrm{O} 3$, if not restricted to the special position, refine to values similar to the low-temperature case ( $x=$ $0.4887, y=0.0158, z=0.4912)$, with a separation O3-O3' of $39.6 \mathrm{pm}$, not significantly different from the low-temperature case $(49.4 \mathrm{pm})$. Finally, the anisotropic refinement with $\mathrm{O} 3$ at the inversion center reveals higher excess difference electron density at the inversion center in the case of the room-temperature data set. This is not consistent with any model of disorder, as lowering the thermal motion should lead to a separation of the two overlayed electron density functions and, thus, increase the differences to the singular function used to fit both of them.

To illustrate and summarize these results we introduce the angle $\alpha$, shown in 1 , as the angle between a plane perpendicular to the axis $\mathrm{Si}-\mathrm{O} 3$ and the vector defined by the two points generated by $\mathrm{O} 3$ as the inversion center for the positions, $\mathrm{M} 1$ to $\mathrm{M} 3$, mentioned above. Table VIII lists the values of $\alpha$. These results underline the fact that none of the types of disorder discussed provide an explanation for the observed phenomena without obtaining 
TABLE VIII. The Deviation Angle from Idealized Geometry for the Models Applied

\begin{tabular}{lll} 
& $\alpha 300 \mathrm{~K}$ & $\alpha 120 \mathrm{~K}$ \\
\hline M1 & 12.7 & 18.3 \\
M2 & 57.0 & 23.6 \\
M3 & 32.8 & 54.1 \\
\hline
\end{tabular}

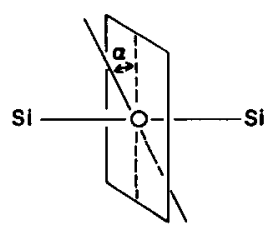

1

chemically unreasonable values for equivalent bonds involved.

Comparison with the data compiled by Ebsworth [13] indicates that there is no dependency of the $\mathrm{Si}-\mathrm{O}-\mathrm{Si}$ angle with the donor or acceptor abilities of the silicon substituents, but the $\mathrm{Si}-\mathrm{O}$ bond length postulates that the $\mathrm{Cp}(\mathrm{CO})_{2} \mathrm{Fe}$ moiety is a strong donor as the value of $d_{\text {Sio }}$ is found between those for $\left(\mathrm{X}_{3} \mathrm{Si}\right)_{2} \mathrm{O}(\mathrm{X}=\mathrm{F}, \mathrm{Cl})$ and $\left(\mathrm{R}_{3} \mathrm{Si}\right)_{2} \mathrm{O}\left(\mathrm{R}=\mathrm{CH}_{3}\right.$, $\mathrm{C}_{6} \mathrm{H}_{5}$ ). This lends credibility to our final conclusion that in the case reported here the $\mathrm{Si}-\mathrm{O}-\mathrm{Si}$ linkage has to be regarded as linear. To further support this statement we are presently attempting to grow crystals of a size suitable for a neutron diffraction analysis.

We found the non-cylindrical distribution of electron density around the oxygen atom in $\left[\mathrm{CpFe}(\mathrm{CO})_{2}\right.$ $\left.\mathrm{Si}\left(\mathrm{CH}_{3}\right) \mathrm{F}\right]_{2} \mathrm{O}$ to be interesting and its origin was probed via molecular orbital calculations of the extended Hückel type. A calculation on $\left[\mathrm{CpFe}(\mathrm{CO})_{2}\right.$ $\mathrm{SiHF}]_{2} \mathrm{O}$, where we have replaced a methyl group on
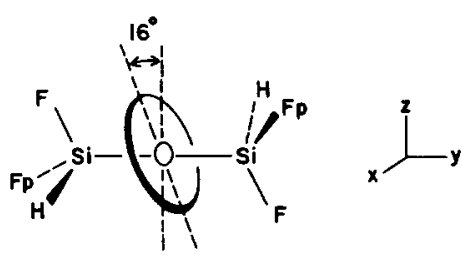

2

each silicon atom for computational ease by a hydrogen atom, revealed that the two lone pairs on oxygen are located in the direction shown by 2 . Here Fp stands for the $\mathrm{CpFe}(\mathrm{CO})_{2}$ substituent. The electron density is tipped $16^{\circ}$ off from the axis normal to the $\mathrm{Si}-\mathrm{O}-\mathrm{Si}$ vector. We are well aware of the approximate nature of extended Hückel calculations, and the relatively close agreement to the value of $\alpha$ (see 1) found for $\mathrm{Ml}$ in the electron density map (Table
VIII, Fig. 3) is probably fortuitous. What is important is that the electron density is tilted towards the fluorine substituents and away from the $\mathrm{Fp}$ groups. This is in the same direction found in the experimental electron density map. Therefore, it is tempting to correlate the two findings, although other explanations may be forthcoming. A coherent analysis of the origin for this deformation can be constructed via perturbation theory; furthermore, this allows one to make predictions about the behavior of related systems. Compounds relevant to these predictions are currently under investigation in our group and may yield corroborative evidence. With this cautionary note we proceed with the analysis of the electronic structure.

The molecular orbitals of 2 are complex. We shall start our analysis from model compounds, starting with the molecular orbitals of the parent siloxane, 3 .<smiles>O[SiH3]</smiles>

A molecular orbital analysis of compounds related to 3 has been presented elsewhere [20]; therefore, we shall only highlight the relevant points. The important valence orbitals of the $\mathrm{H}_{3} \mathrm{Si}$ group are analogous to those of $\mathrm{CH}_{3}$ [24]. They are shown in 4 .

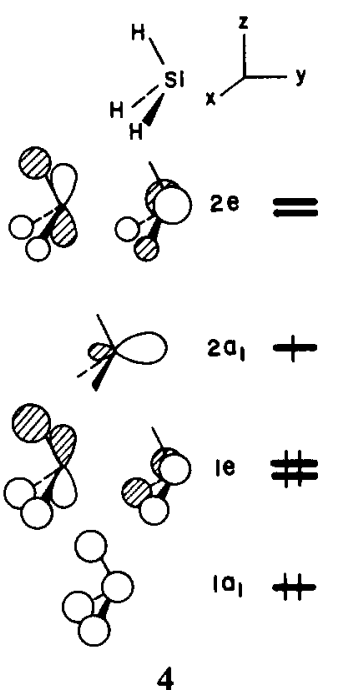

At low energy is a degenerate set of $\mathrm{Si}-\mathrm{H}$ bonding orbitals, labelled le. These, together with $1 a_{1}$, constitute the three $\mathrm{Si}-\mathrm{H}$ bonding orbitals. At higher energy is $2 e$, the $\mathrm{Si}-\mathrm{H}$ antibonding counterpart of 1e. At moderate energy is $2 a_{1}$, which is hybridized out away from the hydrogens, toward the oxygen atom. Clearly, $2 a_{1}$ will be the predominant source of bonding in the $\mathrm{Si}-\mathrm{O}$ bonds.

Figure 4 shows an orbital interaction diagram for building up the molecular orbitals of 3 . On the far 


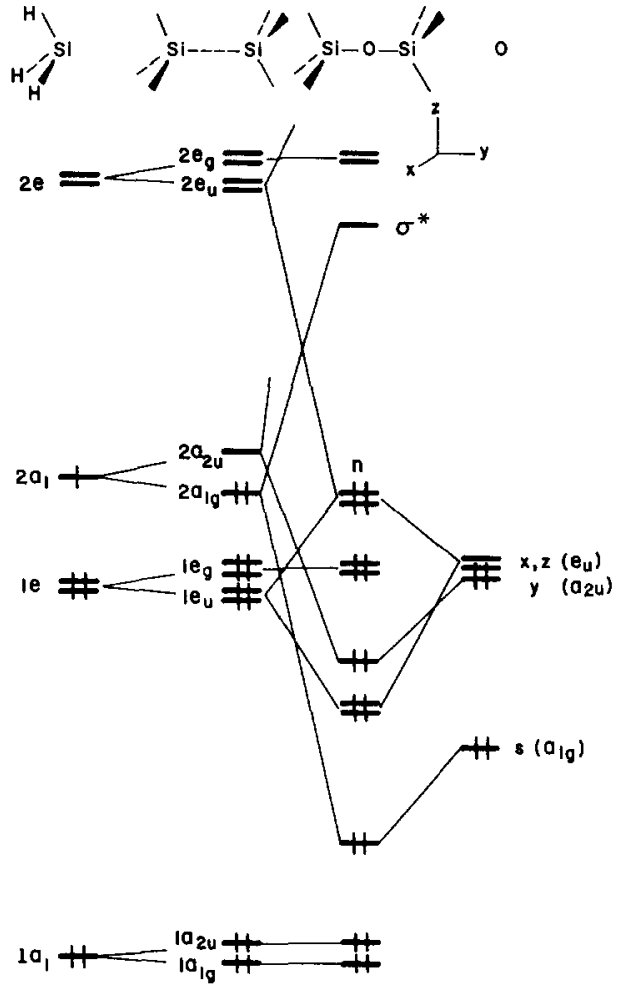

Fig. 4. The interaction diagram for $D_{3 d}\left(\mathrm{H}_{3} \mathrm{Si}\right)_{2} \mathrm{O}$ from two $\mathrm{H}_{3} \mathrm{Si}$ fragments and an oxygen atom.

left are in-phase and out-of-phase combinations of 4. These are labelled according to the $D_{3 d}$ symmetry of the molecule. On the far right are listed the atomic orbitals of the central oxygen atom. The s orbital on oxygen is greatly stabilized by the (in-phase) $2 \mathrm{a}_{1 \mathrm{~g}}$ combination of $2 \mathrm{a}_{1}$. Likewise, $y$ is stabilized by the $2 a_{2 u}$ combination. The other levels are basically nonbonding except for those derived from oxygen $x$ and $z$. These interact appreciably with $1 e_{u}$ and $2 e_{u}$, which, in turn, are derived from $1 \mathrm{e}$ and $2 \mathrm{e}$, respectively, and constitute a classic three-orbital interaction pattern. At low energy is primarily $l e_{u}$, bonding to the oxygen $x$ and $z$ set. At very high energy (not shown in Fig. 1) is an orbital of predominately $2 \mathrm{e}_{\mathrm{u}}$ character, antibonding with respect to $x$ and $z$. The middle 'nonbonding' level, which we have labelled $\mathrm{n}$ in Fig. 4 , is primarily oxygen $x$ and $z$ antibonding to the $1 \mathrm{e}_{\mathbf{u}}$ set and bonding to $2 \mathrm{e}_{\mathbf{u}}$. This is diagrammed in $\mathbf{5 a}$. The resultant orbital set, $\mathbf{5 b}$, has reinforcement at the hydrogens and cancellation at silicon. The reason for bringing up this complication is that contained within $\mathbf{5}$ is the rationale for why there is a very low bending potential for siloxanes and why available structures exhibit a spectrum of $\mathrm{Si}-\mathrm{O}-\mathrm{Si}$ bond angles $[13,16-19,25]$ from $\sim 130^{\circ}$ to the $180^{\circ}$ angle found here in $[\mathrm{CpFe}$ $\left.(\mathrm{CO})_{2} \mathrm{Si}\left(\mathrm{CH}_{3}\right) \mathrm{F}\right]_{2} \mathrm{O}$. Normally, these $\mathrm{AB}_{2}$ molecules with 20 valence electrons are bent. The reasons

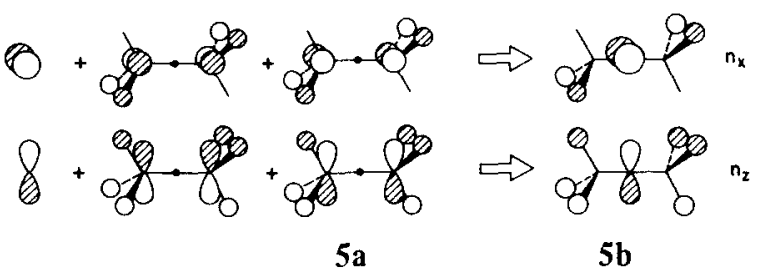

behind this are well-known [26]. So, for example, the $\mathrm{C}-\mathrm{O}-\mathrm{C}$ angles in ethers cluster around 108$110^{\circ}$. In this particular case, $\pi$ bonding between the lone pairs on the oxygen and the silicon serves to keep the $\mathrm{Si}-\mathrm{O}-\mathrm{Si}$ angle large. This has often been ascribed to the intervention of $d$ orbitals on silicon. A more reasoned view [20a] $*$ is that d orbital involvement is quite small. The $2 \mathrm{e}_{\mathrm{u}}$ set serves as a $\pi$-acceptor (see 5a). The extent of $2 \mathrm{e}_{\mathbf{u}}$ mixing with oxygen $x$ and $z$ for any tetrahedral silyl group is much greater than that in an alkyl group [20a]*.

There is one final feature of the electronic structure of $\left(\mathrm{H}_{3} \mathrm{Si}\right)_{2} \mathrm{O}$ that must be discussed - the LUMO of the molecule which is labelled $\sigma^{*}$ in Fig. 4. It consists mainly of the $2 a_{2 u}$ fragment (the out-ofphase $2 a_{1}$ combination) mixed in an antibonding way to oxygen $y$, as is shown in 6 . However, $1 a_{2 u}$ and the antibonding counterpart mix into this orbital with the phase relationships given in 7 . The net result is that $\sigma^{*}$, shown in 8 , contains appreciable character

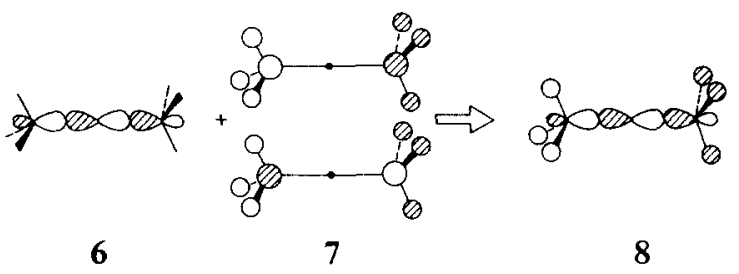

on the hydrogen atoms. Furthermore, hydrogen $s$ is bonding to silicon $\mathrm{s}$ and antibonding to silicon $y$ in $\sigma^{*}$.

The empty $\sigma^{*}$ level mixes into $\mathrm{n}$ when electronegative or electropositive groups are substituted at silicon. This is the dominant effect which serves to reorient the lone pairs on oxygen. As an example, consider the perturbation on going from $\left(\mathrm{H}_{3} \mathrm{Si}\right)_{2} \mathrm{O}$, 3 , to $\left(\mathrm{H}_{2} \mathrm{XSi}\right)_{2} \mathrm{O}, 9$. Here, $\mathrm{X}$ represents an atom more electronegative than hydrogen; furthermore, $\mathrm{X}$ will

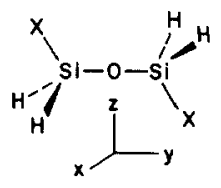

9

* A partial list of literature on d orbital involvement in third-row atoms is given in ref. 27 . 
only be involved in $\sigma$ bonding to the silicon. All orbitals which are antisymmetric to the $y z$ plane (see 9 for the coordinate system) will then be unaffected by the perturbation. The importance of this feature to us is that $\sigma^{*}$ will mix into $n_{z}$ (for the $z$ component of the $\mathrm{n}$ set, see $\mathbf{5 b}$ ), as is shown by $\mathbf{1 0}$. The way in which $\sigma^{*}$ mixes is a familiar result from

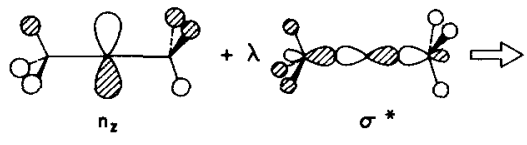

10

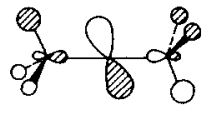

11 perturbation theory [28]. Empty $\sigma^{*}$ mixes into the filled $n_{z}$ orbital in such a way as to increase electron density on the electronegative $\mathrm{X}$ groups. The resultant orbital, 11, contains larger coefficients on $X$, but what is more germane to our study, some oxygen $y$ character from $\sigma^{*}$ is also mixed into 11 , which tilts the orbital on oxygen towards the $\mathrm{X}$ groups. Exactly the opposite situation occurs when a more electropositive group than hydrogen is substituted at silicon (12). Now, $\sigma^{*}$ mixes into $\mathrm{n}_{z}$ with the opposite phase, so that electron density at the electropositive group, $\mathrm{A}$, is diminished. The resultant orbital at oxygen, 13, is tilted away from the A groups. The amount of mixing, given by the mixing coefficient $\lambda$ in $\mathbf{1 0}$, is a function of just how different the electronegativities of $\mathrm{X}$ and $\mathrm{A}$ are, compared to hydrogen. The siloxane system is an ideal one to find this effect since the high electronegativity of oxygen<smiles>[2H][Si]([3H])([3H])O[SiH]([2H])([2H])[3H]</smiles>

12

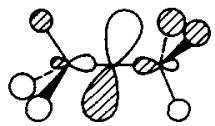

13 and the relative diffuseness of the atomic silicon orbitals make $\sigma^{*}$ lie at low energy. Furthermore, the closer in energy $\sigma^{*}$ is to $\mathrm{n}$, the greater their interorbital mixing will be.

Within the framework of this model it is easy to see how the $\mathrm{n}$ orbitals will be tilted when two substituents of the same type, or a mixed set, are positioned at silicon. Consider the substitution pattern in 14. Now, the molecule has $C_{i}$ symmetry and

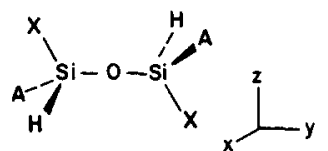

14

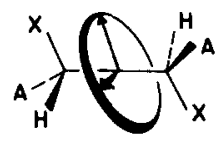

15 both members of the $\mathrm{n}$ set are perturbed. One member of $\mathrm{n}$ is tilted towards the substituents and the other is tilted away from A. The net result is dis- played in 15. This is precisely what was found in $\left[\mathrm{CpFe}(\mathrm{CO})_{2} \mathrm{SiHF}\right]_{2} \mathrm{O}$ (see 2). The fluorines are obviously very electronegative and $\mathrm{CpFe}(\mathrm{CO})_{2}$ is electropositive. Consequently, the lone pairs at oxygen tip towards the fluorines and away from the irons.

The reader should note that we have made this analysis very simple. In actual fact, the $\sigma$ level $\left(2 \mathrm{a}_{1 \mathbf{g}}\right.$ bonding to oxygen $y$ in Fig. 4) also mixes into $n$. The interaction between these two filled molecular orbitals only serves to redistribute electron density within each orbital. Therefore, the net effect of the intermixing between $\sigma$ and $\mathrm{n}$ is cancellation. The electronegativity difference between $\mathrm{X}$ and $\mathrm{H}$ in $\mathbf{1 4}$ is not necessarily the same as that between $A$ and $H$. Recall that these electronegativity differences determine the amount of lone pair tilting. This occurs in our calculations on $\left[\mathrm{CpFe}(\mathrm{CO})_{2} \mathrm{SiFH}\right]_{2} \mathrm{O}$ (see 2). One lone pair lies approximately in the $\mathrm{F}-\mathrm{Si}-\mathrm{O}-$ $\mathrm{Si}-\mathrm{F}$ plane; it is perturbed mainly by the fluorine substituents, and it is tilted $21^{\circ}$ with respect to the $x z$ plane. The orthogonal lone pair is primarily perturbed by the $\mathrm{CpFe}(\mathrm{CO})_{2}$ groups and it is tilted $9^{\circ}$. The $16^{\circ}$ value for the major axis of the ellipse shown in 2 represents the angle made between the vector sum of both lone pairs and its projection onto the $x z$ plane.

The analysis we have presented can easily be extended to other substituent patterns. A diastereomer of 14 is 16, which has $C_{2}$ symmetry. As shown by 17 , the lone pair which lies in the plane of the paper will be perturbed by $\sigma^{*}$ (both orbitals have $b$<smiles>[Y][SiH2]O[SiH]([Y])[Y]</smiles>

16

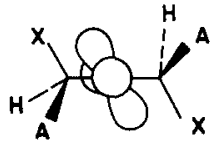

17<smiles>[Y][SiH](C)O[Si]([Y])(C)C</smiles>

18 symmetry). However, the lone pair perpendicular to the plane of the paper is of a symmetry and will not be affected by $\sigma^{*}$; therefore, it is not tilted. An alternative rotomer, $\mathbf{1 8}$, shows similar features, except that the one lone pair is tilted in the opposite direction. Crystals of the other diastereomer of $[\mathrm{Cp}$ $\left.\mathrm{Fe}(\mathrm{CO})_{2} \mathrm{Si}\left(\mathrm{CH}_{3}\right) \mathrm{F}\right]_{2} \mathrm{O}$ which corresponds to the substitution pattern in $\mathbf{1 6}$ or $\mathbf{1 8}$ have been grown (we would favor rotomer 18 on steric grounds). Unfortunately, we have thus far been frustrated in our crystallographic studies of these species by disorder problems.

\section{Acknowledgements}

We thank the Robert A. Welch Foundation (Grants E-594 and E-705) for partial support of this work, as well as NATO for a fellowship to W. Ries. 


\section{References}

1 W. Malisch, C. Burschka and W. Ries, Angew. Chem., in press.

2 D. Cromer and J. Mann, Acta Crystallogr., Sect. A:, 24, 321 (1968).

3 R. F. Stewart, E. F. Davison and W. T. Simpson, J. Chem. Phys., 42, 3175 (1965).

4 'International Tables for X-Ray Crystallography, Vol. III', Kynoch Press, Birmingham, 1967, p. 215.

5 'SHELXTL-User Manual', revision of July 3, Nicolet Corp., 1981.

6 G. M. Sheldrick, 'SHELX-76', A Program for Crystal Structure Determination, Cambridge University, 1976.

7 C. K. Johnson, 'ORTEP II', A Fortran-Ellipsoid Plot Program for Crystal Structure Illustrations, ORNL-5138, Oak Ridge Nat. Lab., Tenn., 1972.

8 R. Hoffmann, J. Chem. Phys., 39, 1397 (1963); R. Hoffmann and W. N. Lipscomb, J. Chem. Phys., 36, 3179 (1962);37, 2872 (1962).

9 T. A. Albright, P. Hofmann and R. Hoffmann, J. Am. Chem. Soc., 99, 7546 (1977); P. Mollère and R. Hoffmann, J. Am. Chem. Soc., 97, 3680 (1975).

10 J. H. Ammeter, H.-B. Bürgi, J. C. Thibeault and R. Hoffmann, J. Am. Chem. Soc., 100, 3686 (1978).

11 W. Hönle and H. G. von Schnering, Z. Anorg. Allg. Chem., 464, 139 (1980).

12 P. G. Jones, Acta Crystallogr., Sect. B., 35, 1737 (1979); J. P. Vidal and J. Falgueirettes, Acta Crystallogr., Sect. B:, 29, 2833 (1973); C. S. Liu, S. C. Nyburg, J. T. Szymanski and J. C. Thomson, J. Chem. Soc., Dalton Trans., 1129 (1972); F. Dahan and Y. Jeannin, J. Orga. nomet. Chem., 171, 283 (1979).

13 M. J. Barrow, E. A. V. Ebsworth and M. M. Harding, Acta Crystallogr., Sect., B:, 35, 2093 (1979) and refs. therein.

14 R. A. Smith and M. J. Benneth, Acta Crystallogr., Sect. $B: 33,1118$ (1977)

15 F. Liebau, Acta Crystallogr., 14, 1103 (1961).
16 W. H. Baur, Acta Crystallogr., Sect. B:, 36, 2198 (1980),

17 W. H. Baur, Acta Crystallogr., Sect. B:, 34, 1751 (1978).

18 G. Glidewell and D. C. Liles, Chem. Commun., 632 (1977); Acta Crystallogr., Sect. B., 34, 124 (1978).

19 F. Bottomley, J. Darkwa and P. S. White, J. Chem. Soc., Chem. Commun., 1039 (1982).

20 (a) T. A. Albright, P. Hofmann and A. R. Rossi, $Z$. Naturforsch., Teil B: 35, 343 (1980); (b) J. A. Tossell and G. V. Gibbs, Acta Crystallogr., Sect. A:, 34, 463 (1978); (c) G. Glidewell, J. Organomet. Chem., 159, 23 (1978); J. Inorg. Nucl. Chem., 38, 669 (1976); Inorg. Chim. Acta, 12, 219 (1975); Inorg. Chim. Acta Rev., 7, 69 (1973) and refs. therein; (d) P. J. Carroll, D. D. Titus, J. Chem. Soc., Dalton Trans., 824 (1977).

21 A. F. Wells, 'Structural Inorganic Chemistry, 4th edn.', Oxford University Press, Oxford, p. 687

22 C. Calvo, Inorg. Chem., 7, 1345 (1968).

23 R. Rudman, 'Low Temperature X-Ray Diffraction Apparatus and Techniques', New York, Plenum, 1976.

24 W. L. Jorgensen and L. Salem, 'The Organic Chemists Handbook of Orbitals', Academic Press, New York, 1973, p. 8,66 ,

25 V. E. Shklover and Yu. T. Struchkov, Usp. Khim., 49, 518 (1980) and refs. therein.

26 C. C. Levin, J. Am. Chem. Soc., 97, 5649 (1975); J. K. Burdett, 'Molecular Shapes', Wiley, New York, 1980, p. 50 ; B. M. Gimarc, 'Molecular Structure and Bonding', Academic Press, New York, 1979, p. 153.

27 D. B. Boyd and R. Hoffmann, J. Am. Chem. Soc., 93, 1063 (1971); R. Hoffmann, D. B. Boyd and S. Z. Goldberg, J. Am. Chem. Soc., 92, 3929 (1970); H. Lischka, J. Am. Chem. Soc., 99, 353 (1977); F. Bernardi, H. B. Schlegel, M.-H. Whangbo and S. Wolfe, J. Am. Chem. Soc., 99, 5633 (1977); H. Wallmeier and W. Kutzelnigg, J. Am. Chem. Soc., 101, 2804 (1979); G. A. Gray and T. A. Albright, J. Am. Chem. Soc., 99, 3243 (1977); M.-H. Whangbo and S. Wolfe, Can. J. Chem., 54, 949 (1976)

28 E. Heilbronner and H. Bock, 'The HMO Model and its Application', Wiley, New York, 1976, p. 156 (W. Martin and A. J. Rackstraw (transl.). 